\title{
JUDESIŲ VALDYMO ŠIUOLAIKINĖS TEORIJOS
}

\author{
Albertas Skurvydas \\ Lietuvos kūno kultūros akademija, Kaunas, Lietuva
}

\begin{abstract}
Albertas Skurvydas. Habilituotas biomedicinos mokslų daktaras. Lietuvos kūno kultūros akademijos Rektorius, Fiziologijos ir kineziterapijos
\end{abstract} katedros profesorius. Mokslinių tyrimų kryptis - motorinės sistemos kompleksinè ir dinaminė adaptacija.

\section{SANTRAUKA}

Šiandien judesiu valdymo ir mokymo tyrimu srityje konkuruoja dvi pagrindinès paradigmos (teorijos): statistine (angl. , ,computational approach“) ir dinaminiu sistemu (angl. „, dynamical system approach“). Statistinès paradigmos požiüriu, judesiu valdymo ir mokymo pagrindinis mechanizmas — tai galvos smegenu gebèjimas , skaičiuoti“ (biologinis kompiuteris). Galvos smegenys skaičiuoja pagal daugeli principu ir dèsniu. Vienas iš populiariausiu principu - Bayes statistika. Anot dinaminiu sistemu paradigmos, judesiu valdymo mechanizmas formuojasi laike. Kitaip tariant, jis kiekvienq karta gali būti kitas. Tai priklauso nuo žmogaus organizmo būsenos, aplinkos specifikos ir žmogaus tikslu. Remiantis skaičiavimo logika, galvos smegenys apskaičiuoja (nustato) motorinès sistemos būsena, büsimo judesio trajektorija, raumenu išugdoma jèga, amplitudę ir pan. Pagrindinis skaičiavimo principas - sudètingumo supaprastinimas. Kitaip tariant, galvos smegenys, valdydamos judesius, galvoje ,ištiesina “ daugelifenomenu, kurie yra netiesiniai periferijoje (pačiame judesyje).

Skaičiavimai dažniausiai naudojami dviem pagrindiniais atvejais: a) prognozuojant judesiu atlikima (iš anksto, be grǐžtamojo ryšio-informacijos apskaičiuojamas judesio atlikimas); b) tikslinant judesiu atlikima (grǐžtamuoju ryšiu). Dinaminiu sistemu požiüriu, galvos smegenys negali spèti apskaičiuoti, pavyzdžiui, visu galimu judesiu trajektoriju, nes tai ne tik neimanoma, bet ir neekonomiška. Todèl manoma, jei ir vyksta skaičiavimas, tai daugeliu atveju spontaniškai, t. y. darant daug klaidu.

Straipsnyje nagrinejamos pagrindinès judesiu savybès (dinamiškumas, spontaniškumas, stabilumas, adaptyvumas) ir šiuolaikinès judesiu valdymo teorijos (refleksiné, hierarchinè, motorinès programos, tikslingoji, informacinè, sistemu, schemos, pusiausvyros taško, dinaminiu sistemu, ekologinè, vidiniu modeliu ir nevaldomos ìvairovés). Didelis demesys kreipiamas i šiu teoriju pritaikymo galimybes sporto ir reabilitacijos srityse.

Raktažodžiai: judesiu savybès, judesiu valdymas, teorijos.

\section{IVADAS}

$\mathrm{K}$ albant apskritai, judesius galima valdyti dviem būdais: valingai (sąmoningai) ir nevalingai. Pirmuoju atveju žmogaus smegenys mąsto inteligentiškai, antruoju - automatiškai (Hastie, Dawes, 2001). Išskirtinis inteligentiško valdymo bruožas yra tas, kad jo metu centrinè nervų sistema prognozuoja ir kuria naujus judesius. Automatiškas valdymas (mąstymas) yra pagrįstas anksčiau išmoktų shemų, šablonų, situacijų automatišku atlikimu.
Šiandien, tiriant judesių valdymą ir mokymą, konkuruoja dvi pagrindinès paradigmos (teorijos): statistinè (angl. ,computational approach") ir dinaminiu sistemu (angl. ,dynamical system

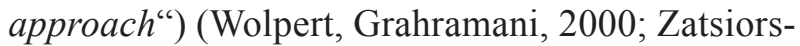
ky, 2002; Todorov, 2004; Shadmehr, Wise, 2005; Kording et al., 2007; Latash et al., 2007; Wolpert, 2007). Statistinès paradigmos požiūriu, judesiu valdymo ir mokymo pagrindinis mechanizmas tai galvos smegenų gebejjimas „skaičiuoti“ (biolo- 
ginis kompiuteris). Galvos smegenys skaičiuoja pagal daugeli principų ir dèsnių. Vienas iš populiariausiu principu - Bayes statistika. Dinaminiu sistemu paradigmos požiūriu, judesių valdymo mechanizmas formuojasi laike. Kitaip tariant, jis kiekvieną kartą gali būti kitas. Tai priklauso nuo žmogaus organizmo būsenos, aplinkos ir tikslų. Žmogaus galvos smegenu „,kompiuteris“ valdydamas judesius skaičiuoja tūkstančius kartu greičiau nei patys tobuliausi kompiuteriai. Ir tai atsitinka ne dèl to, kad žmogaus nervai labai greitai siunčia signalus, bet dèl daugelio unikalių skaičiavimo būdų, kurių tik maža dalis atskleista.

Pavyzdžiui, galvos smegenys apskaičiuoja (nustato) motorinès sistemos būseną, būsimo judesio trajektoriją, raumenų išugdomą jèga, amplitudę ir pan. Pagrindinis skaičiavimo principas - sudettingumo supaprastinimas, kitaip tariant, galvos smegenys, valdydamos judesius, ,ištiesina“ galvoje daugelị fenomenų, kurie yra netiesiniai periferijoje (pačiame judesyje). Skaičiavimai dažniausiai naudojami dviem pagrindiniais atvejais: a) prognozuojant judesių atlikimą (iš anksto, be grižtamojo ryšioinformacijos apskaičiuojamas judesio atlikimas); b) tikslinant judesių atitikimą (grižtamuoju ryšiu). Dinaminių sistemu požiūriu, galvos smegenys negali spetti apskaičiuoti, pavyzdžiui, visu galimu judesiu trajektorijų, nes tai ne tik neimanoma, bet ir neekonomiška. Todèl manoma, jei ir vyksta skaičiavimas, tai daugeliu atvejų spontaniškai, t. y. darant daug klaidų. Šiandien kol kas ginčą laimi statistinè paradigma.

Pats sunkiausias klausimas motorinei sistemai — tai judesio atlikimo būdo pasirinkimas, nes priklausomai nuo kiekvieno išorinio ar vidinio stimulo gali keistis ir judesio atlikimo būdas. Kaip bebūtų keista, daugeliu atvejų judesio atlikimo būdas yra pasirenkamas spontaniškai. Problema: kodėl spontaniškas pasirinkimas dažnai yra toks sèkmingas?

Judesių valdymo kompleksiškumas (sudètingumas) skiriasi nuo judesių kompleksiškumo:

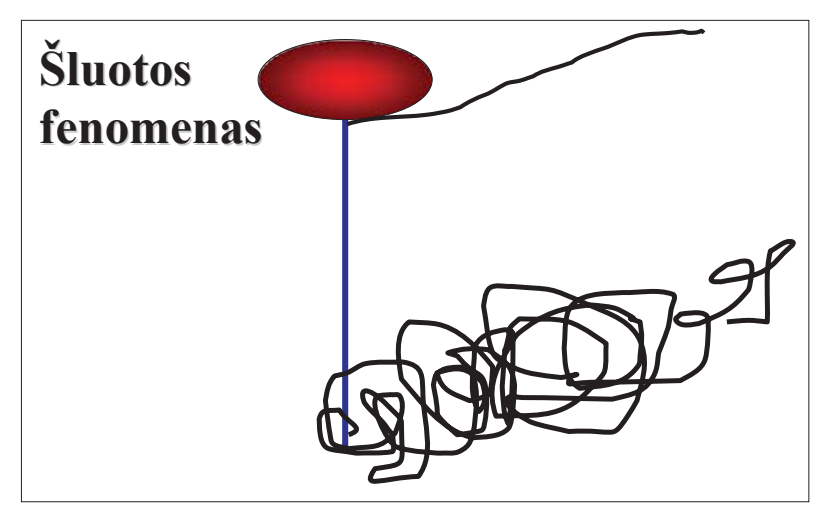

judesys gali būti nesudètingas, bet valdymas labai sudètingas, ir priešingai — valdymas paprastas (nesudètingas), bet judesys kompleksiškas. Dažniausiai judesių mokymosi pradžioje judesių (ir paprastų, ir kompleksiškų) valdymas yra gana sudètingas.

Dabartiniu metu tiriant judesių valdymo neurofiziolginius ir biomechanius mechanizmus, dar nèra galutinai aiškus tikslus judesių valdymo mechanizmas, nèra ir vienos vyraujančios judesio valdymo teorijos. Taigi šio straipsnio tikslas kritiškai apžvelgti pagrindines judesio valdymo teorijas.

\section{PAGRINDINĖS JUDESIŲ SAVYBĖS}

Dinamiškumas. Kiekvieną kartą per kambari nešant ant delno pastatytą šluotą, sėkmingai pasiekiame tikslą, t. y. išlaikome šluotos pusiausvyrą, nors ranka juda, atrodo, chaotiškai (1 pav.). Idomu tai, kad kaskart rankos judejjimo trajektorija bus kitokia. Nèra pasaulyje žmogaus, kuris galètu nešti ant delno pastatytą šluotą tokia pat rankos judejjimo linija. Taip pat nèra dviejų žmonių, gebančių visiškai vienodai atlikti tą pati judesí. Tai ir yra taip vadinamas „Šluotos fenomenas“, kuris gana tiksliai apibūdina judesių dinamiškumą. Tas pats tikslas kiekvieną kartą yra pasiekiamas esant skirtingoms kinematinèms (trajektorija, greičiu) ir dinaminèms (jèga) ypatybėms. Judesių dinamiškumas - tai neišvengiama ir būtina judesių atlikimo savybè (Bernstein, 1967; Kelso, 1999; Zatsiorsky, 2002; van Beers et al., 2004; Davids et al., 2006; Latash et al., 2007; Schoner, Scholz, 2007).

Jei judesiai nebūtų atliekami dinamiškai (kintamai), jie netektų dviejų labai svarbių judesiui savybių: stabilumo ir adaptyvumo (Bernstein, 1967; Kelso, 1999; Burdet et al., 2006; Davids et al., 2006; Latash et al., 2007). Visgi dinamiškumas turi būti optimalus, t. y. nei per didelis, nei per mažas: jei dinamiškumas yra per didelis, tada nukenčia judesio atlikimo tikslumas (pvz., jei reiketu

1 pav. Šluotos fenomenas 
pataikyti šaudant į taikini, kai važiuojame mašina dideliu greičiu per duobètą kelią, o ir taikinys (pvz., kiškis) bėga netiesiai - pataikymo tikimybė nedidelè); mažai dinamiškas judesys labai stabilus, bet ji atliekant apribojama kūrybos laisvè (pvz., jei futbolo vartai būtų apie 50 metru pločio, tai sumažètų žaidimo dinamiškumas ir padidètų pataikymo stabilumas).

Idomu, kad judesio atlikimo kinematinès ir dinamines klaidos yra didesnès nei galutinio tikslo pasiekimo.

Judesių atskiru dalių dinamiškumas nèra vienodas. Pavyzdžiui, kuo arčiau taikinio (tikslo) juda ranka, tuo mažesnis jos trajektorijos kintamumas. Taigi norint iš skirtingu rankos padéčių pirštu pataikyti i nosit, piršto judejimo trajektorija yra kur kas stabilesnė (mažiau dinamiška) nei riešo, alkūnès, peties sąnarių amplitudès ir greičio.

Dinamikos dèsnis - pagrindinis gyvų sistemų dèsnis. Jis rodo, kad motorinès sistemos būsena nuolat kinta laike ir niekados negrižta į tiksliai tą pačią būseną. Kitaip tariant, dinamikos dèsnis tai „laiko strèlès“ dèsnis, t. y. dèsnis, rodantis, kad gyvų sistemų elgsena yra nukreipta į ateiti. Filosofiškai teigiant, pagal dabarti negalima tiksliai prognozuoti ateities, kaip ir pagal dabartį negalima tiksliai suprasti praeities.

Kaip perprasti judesių dinamiškumą (kintamumą)? Kaip ji ivertinti, jei duomenų vidurkinimo metodai iškraipo kiekvieno žmogaus motorinès sistemos unikalumą? Kaip galima valdyti judesius, jeigu jie yra tokie dinamiški? Paskutinis klausimas yra vienas iš svarbiausiu judesių valdymo ir mokymo mokslininkams. Todèl dinamišku (nuolat kintančių) judesių valdymas yra viena iš didžiausių judesių valdymo ir mokymo problemų. Pagrindinis problemos sprendimo būdas - mažinti valdymo sudètingumą (ji supaprastinti) (Scott, 2005); Latash et al., 2007).

Kokia yra motorines sistemos kintamumo prasmé? Keliama hipotezè, kad dèl motorinès sistemos kintamumo raumenims tenka mažesnis krūvis.

Judesiai mažiau kinta judesi atliekant dviem pirštais, o ne vienu (Latash et al., 2007), todèl teigiama, kad kuo daugiau būtinų motorinès sistemos (ir ne tik jos) dalių dalyvauja atliekant judesi, tuo judesys stabilesnis (t. y. nepaisant ịvairių trukdžių, judesys atliekamas patikimiau). Visgi sunku išsiaiškinti, kokios motorinès sistemos dalys yra būtinos konkrečiam judesiui atlikti. Pavyzdžiui, centrinè nervu sistema, valdydama judesius, vadovaujasi nereikalingu judesių mobilizavimo principu — tai reiškia, kad centrinè nervų sistema ieško optimalaus sprendimo judesiui atlikti (Todorov, 2004).

Motorinè sistema turi labai daug galimybiuc atlikti tą pati judesi (pvz., parašyti raidę A - tai galima padaryti judesi atliekant riešu, alkūne, visa ranka, kaire ar dešine ranka, koja, dantimis ir pan.). Tada kalbama apie motorinès sistemos elgsenos ịvairovę (angl. redundancy). Pavyzdžiui, vien per riešo sąnari judesi galima atlikti daugeliu būdų. Kam reikalingas toks begalinis motorinès sistemos dinamiškumas? Manoma, kad dinamiškumas - tai judesiu stabilumo garantas. Dabartiniu metu kinta požiūris: dinamiškumas nèra (kaip seniau buvo teigiama) centrinès nervų sistemos problema - jis greičiau rodo, kad centrinè nervu sistema turi labai daug galimybių rinktis.

Ar žinote, kad jeigu judesys būtu atliekamas visiškai taip pat, jis nebūtu stabilus. Nes optimalus judesiu dinamiškumas (kintamumas) yra judesio stabilumo garantas. Judesio kintamumas yra begalinis, nes kiekviena karta judesys atliekamas šiek tiek pasikeitusioje aplinkoje, ir motorine sistema kaskart yra šiek tiek kitokia, nepaisant to, kad akimi tai sunkiai pastebima. Kiekvienas žmogus judesius atlieka tik jam büdingu dinamiškumu (kintamumu), tačiau mokslininkams iškyla pakankamai sunki užduotis - kaip ji nustatyti?

Spontaniškumas. Motorinè programa kiekvieną kartą susiformuoja spontaniškai, t. y. savaime (Turvey, 1990; Kelso, 1999; Davids et al., 2006). Todèl ir judesio kinematinès ir dinaminès ypatybès gali spontaniškai kisti. Judesių spontaniškumas skiriasi nuo judesių dinamiškumo tik tuo, kad jis daugiau rodo neprognozuojamą (savaimini) judesių atlikimo ypatumų pokyti, o dinamiškumas - judesiu kintamumą. Mokslininkai teigia, kad keičiantis judesių atlikimo greičiui (jègai, amplitudei ir pan.) spontaniškai gali pasikeisti ir judesių atlikimo kokybe (Haken, 1996; Kelso, 1999; Davids et al., 2006). Tai ivvyksta kritiniu laikotarpiu (pereinamuoju). Kritiniu laikotarpiu centrinė nervų sistema gali priimti spontaniškai vienoki ar kitoki sprendimą (pvz., bègti ar sustoti, perduoti kamuoli ar pačiam mesti i krepši, pasukti mašiną i kairę ar į dešinę). Sprendimas priimamas taip greitai ir nevalingai, kad žmogus tik véliau supranta, ką ir kaip padarè.

Viena iš įdomiausių sudètingų sistemų, kurioms priklauso motorinè sistema, savybiu — gebejjimas rinktis optimalią (gal nebūtinai?) elgsenos strategiją iš daugelio alternatyvų. Nebūtinai optimaliausią - tai reiškia, kad tam tikroje situacijoje net „smulkmena“ gali leisti sistemai elgtis pagal 
tokią strategiją, kuri labai tolima optimaliai. Sudètingos sistemos vystymąsi rodo ne kai kuriu jos savybiu patobulejjimas, bet tų savybių reiškimosi tikimybès padidejimas. Be to, labai i̇domu, kad ivykių tikimybès pasiskirstymo forma yra kintanti. Kitaip tariant, i̇vykių tikimybė nėra pastovus dydis - jis nuolatos kinta.

Stabilumas. Judesiu stabilumas priklauso nио optimalaus judesiu kintamumo. Jei žmogus išsitreniruotu atlikti judesį kiek galima stabiliau (t. y. jei kinematinès ir dinaminès judesiu ypatybès būtu stabilios arba mažiau kintančios), tada sumažètu tiksliu ir greitu judesiu atlikimo patikimumas.

Nors judesys kiekvieną kartą yra atliekamas vis kitaip, daugeliu atveju judejjimo tikslas yra pasiekiamas (Bernstein, 1967; Miall, 2002; Zatsiorsky, 2002; Latash et al., 2007). Tai ir vadinama judesiu atlikimo stabilumu. Pavyzdžiui, nors ranka, išlaikydama ant delno pastatytą lazda, juda chaotiškai, tikslas yra pasiekiamas - pusiausvyra išlaikoma. Žmonès daugeliu atveju geba pasiekti tikslą, nepaisant to, kad pats judesiu atlikimas yra kintantis (pvz., žmonès geba vairuoti dvirati važiuodami niekada nematytu keliu ir pan.; jie geba rašyti ne tik dešine, bet ir kaire ranka, koja). Kiekvienas žmogus, kaip ir kiekvienas judesys, turi tam tikrą specifinę stabilumo pasireiškimo tikimybę (pvz., jei ejjimas lygiu paviršiumi daugeliui žmoniu yra gana stabilus judesys, tai ejjimas plonu lynu yra i̇manomas tik nedaugeliui).

Motorines sistemos stabilumas - gebejimas pasiekti tiksla po išorinio sutrukdymo (Burdet et al., 2006).

Dabartiniu metu mokslininkai išskiria dvi judesių stabilumo sampratas. Pagal pirmą sampratą judesiu stabilumas - gebejimas pasiekti tikslą kuo didesne tikimybe (pvz., jei iš 10 baudu žaisdami krepšini pataikome 5, tai kalbame, kad judesio stabilumas siekia 50 procentu). Tuo atveju esame labiau pripratę vietoje stabilumo vartoti tikslumo sąvoką. Pagal antrą sampratą judesių stabilumas — tai gebejjimas priešintis išoriniams trukdžiams (pvz., žmogus išlaiko pusiausvyrą ar nugriūva, jei ji kažkas pastumia $500 \mathrm{~N}$ jèga) (Burdet et al., 2006). Pagal pirmą sampratą tai gali būti vadinama vidiniu motorinès sistemos stabilumu (gebėjimu nepaisyti vidinių trukdžių), pagal antrą - išoriniu stabilumu (gebejimu nepaisyti išorès trukdžių).

Idomu žinoti tai, kad judesiu atlikimas nèra ir negali būti absoliučiai stabilus - ji kaip ir visas kitas gyvas sudètingas sistemas ištinka katastrofos, t. y. neprognozuojamos ir spontaniškos klaidos, kurias gali sukelti kiekviena smulkmena (Kelso, 1999).

Žmogus geba pasiekti tikslą pakankamai stabiliai, tačiau kaskart vis kitaip. Neįmanoma kiekvieną kartą žengti tokio paties ilgio žingsni (jei žmogus gebètų vaikščioti vienodu žingsniu, tai jis greitai nugriūtų, nes toks èjimas nèra stabilus). Todèl kalbama apie tam tikro ilgio žingsnio diapazoną, kuriuo žmogus vaikšto stabiliai. Tas diapazonas gali nuolatos svyruoti priklausomai nuo judejimo greičio, aplinkos trukdžių, motorinès sistemos būsenos (pvz., nuo nuovargio ar treniruotumo). Todèl šnekama apie dinamišką (ar sudètingą), o ne fiksuotą stabilumą.

Adaptyvumas ar gebėjimas mokytis. Negrižztamumas - tvarkos ir pažangos šaltinis. Nieko negalètumème išmokti, jei neveiktu negrižtamumo principas.

Viena iš svarbiausių motorinès sistemos savybiu yra adaptyvumas arba gebejjimas mokytis. Supaprastintai kalbant, motorinè sistema atsimena prieš tai buvusius judesius, ypač originalius, netikètus, dideli ispūdi palikusius. Motorinè atmintis nebūtinai yra valingas procesas, ji pasireiškia mums to nejaučiant. Taigi motorinè sistema, atlikdama judesius, nuolatos mokosi, kaip geriau juos atlikti.

\section{JUDESIŲ VALDYMO TEORIJOS}

Valdyti judesius - tai reiškia apriboti atskiru raumenų ar sąnarių veikimo laisvę ir / ar koordinuoti jų veiklą.

Geros judesiu valdymo teorijos (jei tokia gali būti iš principo) pagrindiniai bruožai turètu büti tokie: a) ji turètu aprépti kuo daugiau judesiu; b) kuo tiksliau prognozuoti judesiu atlikimo veiksminguma ivairiomis situacijomis.

Tradicinis judesių valdymo mechanizmų supratimas yra fiziologinis, o šiuolaikinis — psichofiziologinis. Fiziologinè judesių valdymo teorija nagrinèja judesius mechaniškai, t. $\mathrm{y}$. teigia, kad judesio atlikimo veiksmingumas priklauso nuo žmogaus fiziologinių ir mechaninių ypatybių. Psichofiziologinis judesiu valdymas labiau siejamas su žmogaus psichologija - judesio atlikimo veiksmingumas priklauso ir nuo psichologiniu (būtent nuo žmogaus nuotaikos, interesų, tikslų, judesių atlikimo prasmès ir tikslo supratimo) veiksnių.

Labai grubiai visas judesio valdymo teorijas galima skirstyti i dvi stambias klases: a) teorijas, kurios judesio pradžią kildina iš organizmo vidaus (refleksinę, hierarchinę, motorinès programos, 
2 pav. Hierarchinio valdymo pavyzdys

tikslingają, informacinę, sistemu, schemos); b) teorijas, kurios judesio planavimo pradžią aiškina organizmo ir aplinkos sąveika (dinaminę ir ekologinę).

Refleksinė teorija. Dar šio amžiaus pradžioje susiformavo refleksinè judesių valdymo teorija. Jos pradininkas ižymus fiziologas C. Sherington, kuris 1960 m. parašè knyga ,Integrative Action of the Nervous System“ („Nervų sistemos integracine veikla"). Ši knyga tapo judesiu valdymo ir mokymo teoriniu pagrindu. Refleksinè judesių valdymo teorija grindžiama tuo, kad judesių atlikimo veiksmingumą lemia daugelis tarpusavyje susijusiu refleksų, kurie dažnai yra nukreipti vienam ar kitam judesiui atlikti. Refleksinè judesių valdymo teorija taip pat yra siejama su kitu tų laikų ižymiu fiziologu I. Pavlovu, kuris tyrinejjo sąlyginius ir besąlyginius refleksus. Šių dviejų mokslininkų idejos nèra pamirštos ir šiandien, tačiau dabar yra daug lankstesniu judesiu valdymo teorijų.

Refleksines judesiu valdymo teorijos trūkumai:

1. Refleksas negali būti esminis judesių valdymo elementas.

2. Refleksinè teorija negali paaiškinti, kodèl žmonès ir gyvūnai dažnai geba atlikti judesius be judesiu jausmo ir kodẻl jie geba prognozuoti būsimus judesius.

3. Refleksinè teorija nepaaiškina, kodèl žmonès geba labai greitai ir tiksliai atlikti judesius, nes tada refleksai nebespeja valdyti judesių.

4. Ji negali paaiškinti, kodèl tas pats stimulas gali sukelti daugybę skirtingu atsakų (pvz., priklausomai nuo rankos padèties, vaikas skirtingai ja atitrauks nuo karšto daikto).

5. Refleksinè judesių valdymo teorija negali paaiškinti to fakto, kad vaikas, išmokęs rašyti dešine ranka, tai geba daryti ir kaire. Arba kodèl žmogus geba atlikti daugybę judesių, kurių niekada nèra daręs.

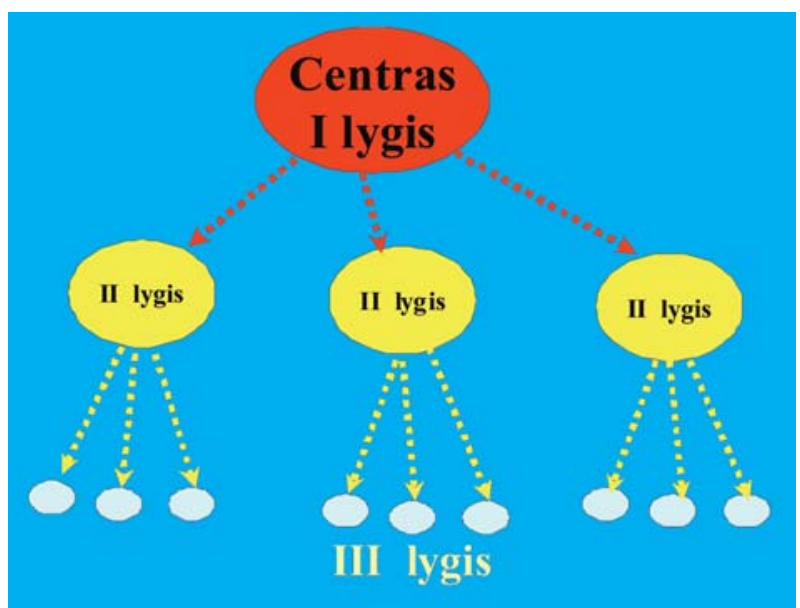

Hierarchinė judesių valdymo teorija. Šios teorijos esmè ta, kad judesių valdymo mechanizmai yra sudèlioti pagal hierarchiją (Brooks, 1986; Enoka, 2002). Kuo aukštesnis judesių valdymo lygis, tuo jis turi didesniu galiu priimti strateginius judesių atlikimo tikslus (2 pav.). Nuo žemesnio hierarchinio lygio mechanizmu priklauso paprastesnių judesių valdymas (pvz., èjimas ar bėgimas), nuo aukštesnio - sudètingos koordinacijos judesių valdymas. Manoma, kad vien galvos smegenyse galima išskirti 3 judesių valdymo lygius. Nuo aukščiausio lygio priklauso judesio atlikimo strategija, nuo vidurinio - taktika, nuo žemiausio - strategijos ir taktikos vykdymas. Žmogaus augimo ir brendimo metu anksčiausiai susiformuoja žemesnio, vèliau aukštesnio lygio mechanizmai. Be to, aukštesnio lygio mechanizmai labiau negu žemesnio priklauso nuo žmogaus motyvavimo, emocijų ar atliekamo judesio supratimo. Tas pats judesys gali būti atliekamas ji valdant skirtingo lygio mechanizmais. Tai priklauso nuo atliekamo judesio tikslo. Pavyzdžiui, pakelti ranką i viršu galima visiškai skirtingu tikslu, būtent: pakèlus i viršų ranką pasiekti kabantị daiktą ar nusiimti nuo lentynos kepurę.

Pagrindinis hierarchinès teorijos trūkumas tas, kad ji negali paaiškinti, kaip atliekant tam tikrą judesi dominuoja tam tikro lygio nerviniai mechanizmai, nes šiandien mokslininkai mano, kad nèra griežtos judesių valdymo mechanizmu hierarchijos.

Motorinès programos teorija. Šios judesių valdymo teorijos esmę sudaro tai, kad atliekamo judesio sékmè priklauso nuo centrinès nervų motorinès programos (Schmidt, Lee, 1999). Manoma, kad jei yra tiksliai suformuota motorinè programa, tai judesys gali būti atliekamas gana tiksliai ir be grį̌tamosios informacijos, t. y. priešingai nei teigia refleksinè ir hierarchinè judesių valdymo teorijos. 
Judesiu valdymo motorines programos teorijos trūkumai:

1. Neatsižvelgiama ị informaciją, gaunamą iš periferijos.

2. Negali paaiškinti, kodèl žmogus geba tiksliai atlikti judesius, kai raumens būsenos skirtingos (pvz., nuvargus). Jeigu judesius valdytų vien tik centrinė nervų programa, tai žmogus beveik negebėtų atlikti judesių tada, kai yra pasilpę raumenys.

Tikslingoji judesių valdymo teorija. Per pastaruosius 50 metų mokslininkai daug naujo sužinojo apie nervini judesių valdymą. Žinių daug igyta, tačiau šiandien dar nèra aiškaus judesiu valdymo mechanizmo supratimo. Manoma, kad vienas iš pagrindinių centrinès nervų sistemos veiklos principu — tikslinga veikla (Latash et al., 2007). Kitaip tariant, atliekamo judesio aiškaus tikslo turèjimas sujungia nervinius mechanizmus i vieną tam tikslui pasiekti. Ši teorija, nors ir gana nauja, tačiau plačiai taikoma tarp kineziterapeutų. Su šios teorijos principais susipažinęs kineziterapeutas žino, kad norint kaip galima greičiau atgauti ligonio judesius būtina jị išmokyti aiškiai suformuoti atliekamo judesio tikslą. Arba, kitaip tariant, ligonio judesio atlikimo veiksmingumas priklauso nuo to, kaip aiškiai jis supranta, ką ir kaip reikia daryti. Labai svarbu, kad ligonis suprastų pagrindinį tikslą ir tik vèliau jis gali būti suskaidomas ị tam tikras dalis. Pavyzdžiui, jei ligoniui būtų nurodoma kiekviena judesio atlikimo detalè, tai nervų sistema negebètu integruotis bendram tikslui pasiekti, nes nèra pagrindinio integruojančio tikslo.

Pagrindinis šios judesiu valdymo teorijos trūkumas - neaiškumas, kaip atliekamo judesio tikslas gali integruoti nervinius mechanizmus bendrai veiklai. Be to, neaišku, koks turi būti tikslas, integruojantis nervinius mechanizmus.

Informacinė judesių valdymo teorija. Jos esmè tokia: judesio atlikimo veiksmingumas priklauso nuo informacijos kiekio apie būsimą ar jau atliekamą judesi. Žinoma daug informacijos perdavimo būdų, pradedant informacija, gaunama iš raumenų, sąnarių, sausgysliu, raiščių, odos ir baigiant rega ar klausa gauta informacija (Wolpert, Grahramani, 2000; Todorov, 2004; Wolpert, 2007). Ši teorija nagrinejja informacijos perdavimo, supratimo ir saugojimo mechanizmus. Dabar valdymo specialistai, pasitelkę i pagalbą kompiuterius, modeliuoja ivairius nervinius ryšius, kurie gali skirtingai perduoti informaciją judesiuc valdymo mechanizmais. Kadangi ši teorija yra palyginti nauja, todèl ji dar mažai paplitusi tarp kineziterapeutų. Visgi ši teorija rekomenduotu atlikti kiek galima daugiau ịvairiu judesių, nes tai padètu asmeniui greičiau atsigauti. Be to, šios teorijos šalininkai turetų suprasti, kad sutrikus vienam nerviniam ryšiui nebūtinai turi sutrikti visa nervų sistema, nes tai gali būti kompensuojama naujų ryšių sudarymu. Jei nerviniai ryšiai ir nenutrūksta, o tik pasilpsta, tai gali atsiliepti visos sistemos darbo veiksmingumui.

Pagrindinis šios teorijos trūkumas — sunkiai konstruojamas ir suprantamas nervinių ryšių modeliavimas.

Sistemų teorija. Ši judesių valdymo teorija siejasi su rusų mokslininko N. Bernšteino darbais (Bernstein, 1967). Juose N. Bernšteinas iškelia idèją, kad žmogaus judesiu valdymas yra sudetingas procesas. Šios teorijos esmè ta, kad judesių valdymo mechanizmai turi ivertinti judesio atlikimo sąlygas ir tuo remdamiesi koordinuoti raumenų veiklą taip, kad judesys būtų atliekamas kiek galima ekonomiškiau (Latash et al., 2007; Wolpert, 2007). Anot N. Bernšteino, judesio atlikimo veiksmingumas priklauso nuo nervų sistemos gebėjimo, atsižvelgiant į raumenų būseną ir žmogaus pozą, parinkti ekonomiškiausią bei veiksmingiausią motorinę programą. Pirmiausia ši judesių valdymo teorija leidžia kineziterapeutams žiūrèti i judesių valdymą kaip į sudètingos sistemos valdymą. Taip pat ši teorija, ypač akcentuodama mechanines raumenų, sąnarių savybes, leidžia kineziterapeutams suprasti, kad norint atgauti judesius būtina ivvertinti ir biomechanines atliekamo judesio savybes. Vadinasi, reikia ieškoti patogiausių padèčių, kurios leistų ligoniams atlikti judesius. Prie tu padéčiu reikètų pratinti motorinę programą. Kitas pavyzdys: jei raumuo nèra pakankamai sustiprejjęs, tai gali būti pagrindinè ligonio negalejjimo vaikščioti ar stovèti priežastis. Be to, kineziterapeutai turètu žinoti, kad judesių veiksmingumas priklauso ne nuo vienos motorinès sistemos dalies darbo kokybès, bet nuo visos sistemos.

Didžiausias N. Bernšteino indèlis i judesiu valdymo ir mokymo mokslo samprata buvo toks:

1) jis pirmasis apraše judesiu laisvès laipsniu problema - kuo didesnis judesio laisvès laipsnis, tuo sunkiau valdyti toki judesi;

2) nurode, kad motorinès sistemos periferijos (raumenu) būsena yra nuolatos kintanti - tai dar viena centrinès nervu sistemos problema;

3) pirmasis apraše funkcinès sinergijos svarbajudesiu valdymui (sinergija - tai organizmo daliu tarpusavio ir aplinkos darni squeika tikslui pasiekti). 
Pagrindinis sistemu teorijos trūkumas yra tas, kad valdant judesius neatsižvelgiama į aplinkos pokyčius, kurie neišvengiami žmogui judant.

Schemos teorija. Schemos teorijos esmè galvos smegenys suformuoja generalinę (bendraja) motorinę programa, kuri igyvendinama pagal tam tikras igimtas ar igytas taisykles, principus (schemas) (Schmidt, Lee, 1999).

Pusiausvyros taško hipotezè. Pusiausvyros taško hipotezè (angl. equilibrium point hypothesis) - judesiu valdymo teorija-hipotezè, pagal kurią judesių valdymo mechanizmo pagrindinè paskirtis — garantuoti raumens išugdomos jègos ir išorinio poveikio (pvz., keliamo svorio) jègos pusiausvyrą (Latash et al., 2007). Ši pusiausvyra yra garantuojama automatiškai (refleksais). Manoma, kad CNS, valdydama judesius, nustato reflekso jautrumą. Pagrindinis refleksas šiuo atveju yra tempimo (ypač toninis) refleksas. Todèl CNS nustato reflekso jautrumo dydžius esant tam tikram raumens ilgiui.

Dinaminių sistemų teorija. Ši teorija yra viena iš naujausių judesių valdymo teorijų (Zelaznik, 1996; Kelso, 1999; Davids et al., 2006). Ji papildo judesių valdymo sistemu teoriją atkreipdama dèmesi $i$ tai, kad kintanti aplinka veikia judesiu valdymą. Vienas iš pagrindinių šios teorijos principu - judesiu valdymo mechanizmai yra save valdantys. Valdymo paradigma neišskiria centrinio valdytojo. Ši teorija yra kur kas lankstesnè nei anksčiau aprašytos, nes ja remiantis judesiai gali būti valdomi ir be centrinès motorinès programos. Kiekvienam konkrečiam judesiui atlikti gali būti suformuota skirtinga valdymo programa.

Pagrindinis dinamiško valdymo veiksnys tai dinamiška judesio tikslo, motorinès sistemos būsenos ir aplinkos specifikos sąveika. Dinaminè teorija leidžia paaiškinti judesių kintamumo prigimti. Būtent judesiai kinta dèl nuolatinès triju pagrindiniu ,žaidèjų“ kaitos — judesio tikslo (užduoties), motorinès sistemos būsenos ir aplinkos. Visgi judesių kintamumas, anot dinaminès judesių valdymo teorijos, nèra trūkumas, priešingai - tai daugeliu atveju privalumas (Latash et al., 2007). Nepaisant judesių kintamumo svarbos, dinamine teorija dideli démesi skiria judesių stabilumui, kuris suprantamas ne kaip statinis (fiksuotas), bet kaip dinaminis stabilumas. Dinaminio stabilumo pagrindas yra atraktorius (angl. attractor) arba siekiama motorinès sistemos būsena. Kuo ši prognozuojama būsena yra labiau siekiama (realiai siekiama), tuo yra stipresnis atraktorius. Vadinasi, motorinè sistema turi didesnę tikimybę transfor- muotis i šią būseną (judesys pasieks tikslą). Du pagrindiniai parametrai - tvarkos ir valdymo veikia judesio atlikimą (valdymą). Tvarkos (arba kolektyvinis) - nustato motorinès sistemos atskirų daliu tarpusavio sąveikos bei jų ir aplinkos sąveikos būdus (principus, taisykles), valdymo valdo tvarkos parametrą (pvz., judejimo krypti, tempa, greiti, amplitudę ir pan.) (Kelso, 1999). Pagal dinaminių sistemu judesių valdymo modeli judesiui atlikti nereikia struktūrizuotos programos ir labai tikslaus jos igyvenimo mechanizmo. Judesių valdymas pagal dinaminį modelị priklauso nuo dinamiškos judesio užduoties, motorinès sistemos būsenos ir aplinkos sąveikos. Pavyzdžiui, pagal tą pačią užduoti (arba motorinę programą) galima ir pataikyti, ir nepataikyti spirti $\mathfrak{i}$ kamuoli.

Anot dinaminiu sistemu teorijos, judesiu kinematinès ir dinaminès ypatybès (greitis, amplitudè, jèga) greičiau kinta nei visas judesio stilius, braižas (tvarkos parametras). Pavyzdžiui, parašo braižas (stilius) išlieka unikalus net ir pasirašant koja.

Pagrindinis šios teorijos trūkumas — ne jos veikimo būdai, bet jos supratimas, nes suprasti šią teorija gana sunku.

Ekologinè judesių valdymo teorija. Ši judesių valdymo teorija yra viena iš jauniausių, nors pirmas šios teorijos idejas dar 1960 metais skelbe ižymus psichologas J. Gibson (1979). Ši teorija siejasi su dauguma anksčiau minètų teorijų, tačiau atkreipia dèmesi $i$ aplinkos poveiki judesiu valdymo veiksmingumui (Davis, Broadhead, 2007). J. Gibson manè, kad žmogaus regéjimo sistema leidžia iš karto pagauti pačią svarbiausią informacija, reikalinga judesiui atlikti. Dar vienas išskirtinis ekologinès teorijos bruožu yra tas, kad pradèti judesi dažnai nurodo aplinka, o ne žmogaus organizmo vidus. Manoma, kad iš visų informacijos šaltinių apie atliekamą ar būsimą judesi pats svarbiausias yra žmogaus padètis erdvejje. Be to, teigiama, kad žmogus iš prigimties centrinejje nervų sistemoje turi aplinkos ,žemėlapi““, kuriuo vadovaujasi atlikdamas ivairius judesius.

Pagrindinis šios teorijos trūkumas: ja negalima paaiškinti visų ir mažiau nuo aplinkos pokyčiu priklausančių judesių valdymo.

Judesių valdymas vidiniais modeliais ir optimaliu valdymu suteikiant grižtamąją informaciją. Pagrindiniai šios teorijos parametrai yra šie: 1) motorinès sistemos pradinès būsenos nustatymas; 2) judèjimo tikslo (taikinio) nustatymas; 3 ) patirties apie anksčiau buvusius panašius judesius įvertinimas (atlikimo erdvès pločio nu- 
statymas); 4) idealios trajektorijos modeliavimas (tai atlieka atvirkščias vidinis modelis); 5) judesio programos, kuri atitiktų esamą situaciją, atlikimo erdvę ir idealią trajektoriją, sudarymas (taikant Bayes taisyklę); 6) realios judesio trajektorijos koregavimas, kuri atlieka optimalaus valdymo su grį̌tamaja informacija modelis (Todorov, 2004; Wolpert, 2007). Judesys koreguojamas tik tada, kai judesio atlikimo reali trajektorija išeina iš judesio atlikimo erdvès.

Ši judesių mokymosi teorija yra pagrista Bayes skaičiavimo taisykle, teigiančia, kad atsižvelgiant i motorinès sistemos esamą būseną, aplinkos situaciją, atliekamo judesio užduotị ir prieš tai buvusio (ar buvusių) judesio atlikimo rezultatus yra apskaičiuojamas optimalus būdas (iš daugelio kitų) reali judesio trajektorija judesiui atlikti (Wolpert, 2007). Viena iš dižiausių Bayes skaičiavimo problemu — kaip iš daugelio atrinkti tinkamiausią būdą judesiui atlikti. Gana sunku nustatyti, kas yra optimalu (kokie optimalumo kriterijai). Vienas iš svarbiausių kriterijų — pasiekti tikslą kuo mažiau sunaudojant energijos.

Judesių mokymas pagal Bayes taisyklę tai procesas, kurio metu apskaičiuojama judesio atlikimo būdo tikimybė. Vienas iš svarbiausiu etapu — išankstinis spejimas apie, tarkim, judesio trajektorija. Šis spejimas yra tikimybinis ir remiasi ankstesne patirtimi - kuo didesnè patirtis, tuo tikslesnis spejimas (hipotezè). Prieš pradedant atlikti judesi, galvos smegenys gauna papildomos informacijos (duomenu) apie kūną ir aplinką (pvz., kokiu greičiu lekia kamuolys). Tada galvos smegenys nustato tos informacijos reiškmosi tikimybę spejimo (hipotezès) atžvilgiu. Pagaliau galvos smegenų motorinè žievè priima sprendima, ivertindama kokia tikimybe spejjimas (hipotezè) atitinka duomenis (informaciją). Šiuo etapu dar būtina ivertinti informacijos patikimumą.

Nevaldomos iqvairovès hipotezė. Nevaldomos ivairovès hipotezè (angl. uncontrolled manifold hypothesis) yra viena iš naujausiu judesiu valdymo teoriju (Scholz, Schoner, 1999; Zatsiorsky, 2002; Latash et al., 2007). Jos pagrindiniai akcentai yra šie: judesių valdymas yra pagrịstas sinerginiu mechanizmu ir sistemos susireguliavimo principu. Sinerginio mechanizmo trys pagrindiniai komponentai: a) lankstumas; b) klaidų automatiškas ištaisymas - jei sistemos tam tikra dalis padare klaida, tai ją automatiškai ištaiso kita dalis; c) veiklos paskirstymas tarp sistemos dalių — visos sistemos dalys dalyvauja atliekant judesi (nereikalingų dalių nèra) (Latash et al., 2007). Anot nevaldomos ivairovès hipotezès, judesių kintamumas yra būtinas norint stabiliai atlikti judesį. Visgi kintamumas būna ir „geras“, ir „blogas“. „Geras“ kintamumas dideja tada, kai mokomès atlikti judesius, o „blogas" - mažèja. Galvos smegenims daugiausia naudos duoda „geras" kintamumas, nes jo nereikia valdyti (kontroliuoti). Pavyzdžiui, dviem pirštais norime išugdyti $10 \mathrm{~N}$ jẻgą: jei vienas pirštas išugdo $4 \mathrm{~N}$, tai kitas — apie $6 \mathrm{~N}$. Svarbu, kad suma išliktų apie 10 N. Tada nereikia valdyti atskirai kiekvieno piršto jègos, užtenka valdyti tik pirštuc išugdomos jègos sumą. Kuo mažiau centrinei nervų sistemai reikia valdyti, tuo tobulesnis yra valdymo mechanizmas.

\section{IŠVADOS}

Dabartiniu metu vyrauja šios judesių valdymo teorijos: dinaminiu sistemų, ekologinè, nevaldomos įvairovès hipotezè ir vidinių modelių. Jas jungia bendras judesiu valdymo principas, t. y. galvos smegenys sukuria ir igyvendina motorinę programą (manoma, kad galvos smegenys geba „apskaičiuoti“ optimalius judesių valdymo mechanizmus), atsižvelgiant ị organizmo, aplinkos ir judesio tikslo dinamišką sąveiką. Deja, mokslininkams dar reikia daug padirbèti norint išsiaiškinti judesių planavimo ir igyvendinimo (,skaičiavimo") neurofiziologinius mechanizmus.

\section{LITERATŪRA}

van Beers, R. J., Haggard, P, Wolpert, D. M. (2004). The role of execution noise in movement variability. Journal of Neurophysiology, 91 (2), 1050-1063.

Bernstein, N. (1967). The Co-ordination And Regulation Of Movements. London: Pergamon Press.

Brooks, V. B. (1986). The Neural Basis of Motor Control. Oxford: Oxford University Press.

Burdet, E., Tee, K. P., Mareels, I. et al. (2006). Stability and motor adaptation in human arm movements. Bioogicall Cybernetics, 94 (1), 20-32.

Davids, K., Bennet, S., Newell, K. (2006). Movement Sys- tems Variability. Champaign, IL: Human Kinetics.

Davis, W. E., Broadhead, G. G. (2007). Ecological Task Analysis and Movement. Champaign, IL: Human Kinetics.

Enoka, R. (2002). Neuromechanics of Human Movement. Champaign, IL: Human Kinetics.

Gibson, J. J. (1979). The Ecological Approach to Visual Perception. Boston, MA: Houghton-Mifflin.

Haken, H. (1996). Principles in Brain Functioning. A Synergetic Approach to Brain Activity. Berlin, Heidelberg, New York: Springer. 
Hastie, R., Dawes, R. M. (2001). Rational Choice in an Uncertain World: The Psychology of Judgment and Decision Making. Sage Publications, Thousand Oaks, CA.

Kelso, J. A. S. (1999). Dynamic Patterns: The Self-Organization of Brain and Behavior. Cambridge: MIT Press.

Kording, K. P, Tenenbaum, J. B., Shadmehr, R. (2007). The dynamics of memory as a consequence of optimal adaptation to a changing body. Nature Neuroscience, 10 , 779-786.

Latash, M. L., Scholz, J. P., Schoner, G. (2007). Toward a new theory of motor synergies. Motor Control, 11, $276-308$.

Miall, R. C. (2002). Motor control, biological and theoretical. In M. A. Arbib (Ed.), Handbook of Brain Theory and Neural Network, 2nd ed. (pp. 686-689). Cambridge MA: Bradford Books, MIT Press.

Schmidt, R. A., Lee, T. D. (1999). Motor Control and Learning: A Behavioral Emphasis. Champaign, IL: Human Kinetics.

Scholz, J. P., Schoner, G. (1999). The uncontrolled manifold concept: Identifying control variables for a functional task. Experimental Brain Research, 126, 289-306.

Schoner, G., Scholz, J. P. (2007). Analyzing variance in multi-degree-offreedom movements: Uncovering struc- ture versus extracting correlations. Motor Control, 11, $259-275$.

Scott, S. H. (2005). Conceptual frameworks for interpreting motor cortical function: New insights from a planar multiple-joint paradigm In motor cortex in voluntary movements. A. Riehle, E. Vaadia (Eds.) (pp. 157-180). London: CRC Press.

Shadmehr, R., Wise, S. P. (2005). Computational Neurobiology of Reaching and Pointing: A Foundation for Motor Learning. Cambridge MA: MIT Press.

Todorov, E. (2004). Optimality principles in sensorimotor control. Nature Neuroscience, 7 (9), 907-915. Review.

Turvey, M. T. (1990). Coordination. American Psyhology, 45, 938-953.

Wolpert, D. M., Grahramani, Z. (2000). Computational principles of movement neuroscience. Nature, 3, 12121217.

Wolpert, D. M. (2007). Probabilistic models in human sensorimotor control. Human Movement Science, 26 (4), $511-524$

Zatsiorsky, V. M. (2002). Kinetics of Human Motion. Champaign, IL: Human Kinetics.

Zelaznik, H. N. (1996). Advances in Motor Learning and Control. Champaign, IL: Human Kinetics.

\title{
CONTEMPORARY THEORIES OF MOTOR CONTROL
}

\author{
Albertas Skurvydas \\ Lithuanian Academy of Physical Education, Kaunas, Lithuania
}

\begin{abstract}
Nowadays two main paradigms (theories) compete in motor control and motor learning research: computational approach and dynamical system approach. From the standpoint of computational approach the main mechanism of motor control and learning is the ability of the brain to "compute" (biological computer). The human brain computes applying many approaches and laws. One of the most popular approaches is Bayes statistics. According to the paradigm of dynamical systems the mechanism of motor control develops in time. That is to say, every moment of time it can be different. It depends on the state of the human body, specificity of the environment and personal aims. Referring to computational logic, for example, the human brain computes (estimates) the state of the motor system, the trajectory of the upcoming movement, the force developed by the muscles, the range, etc. The main computational approach is simplifying the complexity; that is to say, during motor control the human brain "straightens" many phenomena in the mind which are nonlinear in the periphery (in the movement itself).

Computations are used in two main cases: a) for the performance of predicted movements (motor performance is estimated beforehand, without feedback) and b) computation with constant revision (feedback). According to the dynamical system approach the human brain cannot compute e. g. all the possible trajectories of movements in time because it is not only impossible but also uneconomical. Thus, in many cases computing is spontaneous and with "broken figures", i. e. with many mistakes.

The article deals with the main motor abilities (dynamism, spontaneity, stability, adaptivity) and contemporary theories of motor control (reflexive, hierarchical, motor program, expedient, informational, system, scheme, balance point, dynamic systems, ecological, inner patterns and uncontrolled diversity). Much attention is paid to the possibilities of the application of those theories in sport and rehabilitation.
\end{abstract}

Keywords: motor abilities, motor control, theories.

Gauta 2009 m. kovo 31 d.

Received on March 31, 2009

Priimta 2009 m. gegužès 26 d

Accepted on May 26, 2009
Albertas Skurvydas

Lietuvos kūno kultūros akademija

(Lithuanian Academy of Physical Education)

Sporto g. 6, LT-44221 Kaunas

Lietuva (Lithuania)

Tel +37068614700

E-mail a.skurvydas@1kka.1t 